\title{
The Effect of Grape Seed Extract on the Pancreatic Weight in Diabetic Rats
}

\author{
Diyabetik Sıçanlarda Üzüm Çekirdeği Ekstresinin Pankreas Ağırlığına Etkisi
}

\author{
(1) Elif Gülbahçe Mutlu¹, (D) Emine Arslan², (1) Hilal Arıkoğlu33, (1) Salih Varol ${ }^{4}$ \\ ${ }^{1}$ KTO Karatay University Faculty of Medicine, Department of Medical Biology, Konya, Turkey \\ ${ }^{2}$ Selçuk University Faculty of Science, Department of Biology, Konya, Turkey \\ ${ }^{3}$ Selçuk University Faculty of Medicine, Department of Medical Biology, Konya, Turkey \\ ${ }^{4}$ KTO Karatay University Faculty of Medicine, Department of Physiology, Konya, Turkey
}

\begin{abstract}
Objective: The pancreas is a vital organ that produces metabolic hormones and enzymes. Type II diabetes either arises from defective insulin secretion from pancreatic beta-cell cells or a diminished pancreatic beta-cell mass. The possible effects of grape seed extract on various metabolic diseases have been investigated in recent years. This study was designed to determine the effect of grape seed extract therapy on pancreatic mass.

Methods: Twenty-five rats were partitioned in five groups: control, diabetes and treatment groups in which was administered 100, 200, and $400 \mathrm{mg} / \mathrm{kg}$ of the grape seed extract, respectively. Regarding the origin of diabetic rats, $35 \mathrm{mg} / \mathrm{kg}$ of STZ was injected intraperitoneally into the diabetic control and treatment groups. The grape seed extract was administered to the treatment groups via gavage per the indicated doses $(100,200$, and $400 \mathrm{mg} / \mathrm{kg}$ extract) for 28 days. All rats were dispatched post treatment. After dispatching the rodents, their pancreatic masses were obtainedand noted. Data analysis was performed in order to determine the differences between groups using the Statistical Package for Social Sciences version 22-SPSS (IBM Statistics 22).

Results: The pancreatic mass in diabetic rats was significantly $(p<0.05)$ lower relative to the control rats. Equally, the pancreatic increased significantly in every treatment group compared to the control and diabetic groups $(p<0.05)$. This increase was highest with the $400 \mathrm{mg} / \mathrm{kg}$ extract dose.
\end{abstract}

Conclusion: Grape seed extracts might be effective reversing pancreatic insufficiency in STZ-diabetic rats.

Keywords: Experimental diabetes mellitus, grape seed extract, pancreas, streptozotocin

\section{öz}

Amaç: Pankreas metabolik hormonlar ve enzimler üreten hayati bir organdır. Tip II diyabet, pankreatik beta hücre hücrelerinden insülin sekresyonundaki bir başarısızlıktan veya pankreatik beta hücre kütlesindeki bir azalmadan kaynaklanır. Üzüm çekirdeği ekstresinin çeşitli metabolik hastalıklar üzerindeki olası etkileri de son yıllarda araştıılmaktadır. Bu çalışma, üzüm çekirdeği ekstresi tedavisinin pankreas ağırlığı üzerindeki etkisini belirlemek için tasarlanmıştır.

Gereç ve Yöntem: Yirmi beş sıçan beş gruba ayrıldı: Sırasıyla 100, 200 ve 400 mg/kg ekstrakt uygulanan kontrol, diyabet ve tedavi grupları. Diyabetik sıçanlar oluşturmak için $35 \mathrm{mg} / \mathrm{kg}$ doz STZ diyabet kontrol ve tedavi gruplarına introperitonal olarak enjekte edildi. Üzüm çekirdeği ekstresi 28 gün boyunca belirtilen dozlarda (100, 200 ve 400 mg/kg ekstrakt) gavaj yoluyla tedavi gruplarına verildi. Tüm sıçanlar tedavi sonrası sakrifiye edildi. Sekrifiye edildikten sonra pankreas ağırıkları tartıldı ve not edildi. SPSS yazılımı (IBM Statistics 22) kullanılarak gruplar arasındaki farkları belirlemek için istatistiksel analizler yapıldı.

Sonuç: Diyabetik sıçanlarda pankreas ağırlığı, kontrol sıçanlarına göre anlamlı olarak daha düşüktü ( $p<0,05)$. Ayrıca pankreas ağırlığı kontrol ve diyabet gruplarına göre tüm tedavi gruplarında anlamlı olarak artmışıı $(p<0,05)$. Bu artış, 400 mg/kg ekstrakt dozunda en yüksekti.

Sonuç: Üzüm çekirdeği ekstresi, STZ-diyabetik sıçanlarda pankreatik yetmezliği düzeltmede etkili olabilir.

Anahtar Kelimeler: Deneysel diabetes mellitus, üzüm çekirdeği ekstresi, pankreas, streptozotosin

Address for Correspondence: Elif Gülbahçe Mutlu, KTO Karatay University Faculty of Medicine, Department of Medical Biology, Konya, Turkey

Phone: +90 5424257468 E-mail: elifgulbahcemutlu@gmail.com ORCID ID: orcid.org/0000-0003-2391-2152

Cite as: Gülbahçe Mutlu E, Arslan E, Arıkoğlu H, Varol S. The Effect of Grape Seed Extract on the Pancreatic Weight in Diabetic Rats.

Med J Bakirkoy 2021;17:293-297

Received: 03.03.2021

Accepted: 01.11.2021 


\section{INTRODUCTION}

The pancreas is a vital endocrine and exocrine organ that produces different hormones and enzymes (1). An altered function in this organ could directly influence the physiological functions of the body $(2,3)$. Type II diabetes occurs when the pancreas is unable to meet the metabolic needs resulting either from a i pancreatic $\beta$-cells dysfunction of insulin production or decreased beta-cell mass $(4,5)$. Diabetes is one of the prevalent non-communicable diseases globally. It is disease characterized by a chronic hyperglycemia. In recent times, the global prevalence of diabetes has been rising steadily. It is believed by the International Diabetes Federation that the total number of diabetic victims worldwide will be approximately 642 million (6).

Streptozotocin (STZ) is a biochemical agent obtained "streptomycetes achromogenes" exhibiting diabetogenic properties and widely used in the generation of experimentally induced diabetes in animals $(7,8)$. It was first reported by Rakieten that STZ selectively affects $\beta$-cells in Langerhans islets and has a highly specific diabetogenic effect (9). Its initial effect constitutes inhibiting $\beta$-cell response to glucose (10), followed by permanent cell damage and loss of function (11).

Traditional insulin treatment is inadequate due to reasons such as supply, storage and side effects, especially in developing countries. Thus, in recent times, newly developed alternatives include the use of natural or synthetic antidiabetic agents $(12,13)$. Also, herbal therapies have been used in the management of diabetes in various regions in our country, as a result scientific studies are being carried to investigate thee hypoglycemic properties of these medicinal herbs (12).

Grape seed was first extracted in France in 1951 and was initially found to have auxiliary effects with vitamin C (14). Grape seeds are an important source of antioxidants because they are rich in flavonoids like catechin, epicatechin, procyanidins, anthocyanins, gallic acid, and phenolics such as ellagic acid, as well as stilbenes such as resveratrol and piceid (15). It has been reported to have beneficial effects on insulin resistance or diabetes, which occurs due to a decrease in the antioxidant content of the body $(16,17)$. Grape seeds have not been reported by any study to have any in vivo side effects till date. However, it has been used as a nutritional supplement in America and Europe for many years. In addition, grape seed is included in the GRAS (generally considered safe) category by the U.S. Food and Drug Administration. The recommended daily dose of grape seed is between 100 and $300 \mathrm{mg}$ (18).
The aim of this study was to investigate the effect of grape seed extracts on the pancreatic mass of rats on a high-fat diet and induced with low-dose STZ.

\section{METHODS}

\section{Preparation of Grape Seed Extract}

In this study, the red Globe grape seed (Vitis vinifera L.) varieties were used. Grape seeds, which constitute the herbal agents of the study, were separated from the cluster and their seeds were extracted. These seeds were then washed and dried at room temperature on blotter paper. The dried grape seeds were crushed into the powdered form and later extracted using the Downey et al. (19) method. The crude extract obtained was weighed to calculate the extraction efficiency afterwhich it was then lyophilized. The lyophilized extract was later dissolved in distilled water at concentrations of $100 \mathrm{mg} / \mathrm{kg}, 200 \mathrm{mg} / \mathrm{kg}$, and $400 \mathrm{mg} / \mathrm{kg}$.

\section{Creating Experimental Diabetic Animal Model}

Ethical approval for this study was obtained from the Konya Necmettin Erbakan University Experimental Medical Research Ethics Committee and Application Center for this study (decision no: 2013/005). In this study, the WistarAlbino race rats (8-12-week-old female) for the experiment. The experimental rodents were obtained from the Konya Necmettin Erbakan University Experimental Medical Research and Application Center. The ages and especially live weights of the subjects were provided to be similar. They were housed at $220 \mathrm{O} \pm 2 \mathrm{oC}, 12$ hours in a dark and 12 hours in a lighted environment. Feed and water were provided as ad libitum. Blood samples were collected from rats that completed the adaptation phase, the fasting blood sugar levels and lipid profiles were determined. In animals with statistically similar lipid profiles $(p<0.05)$, an experimental type II diabetes model was induced according to the Srinivasan et al. method (20). The rats used in this study were separated into five groups as follows; the control group, the diabetes group and treatment group with 100, 200, and $400 \mathrm{mg} / \mathrm{kg}$ extracts administerd respectively. In order to experimentally induce diabetes, $35 \mathrm{mg} / \mathrm{kg}$ dose of STZ was dissolved in citrate buffer ( $\mathrm{pH}$ 4.5) and administered as an intraperitoneal injection to rats in the diabetes and treatment groups. After 72 hours, the caudal vein blood sugar levels of the rats were measured with the aid of an autoanalyzer (Biotecnica Instruments, BT3000 Plus, Italy). Following this measurement, rats above $300 \mathrm{mg} / \mathrm{dL}$ were considered diabetic and included in the study (20). 


\section{Applying the Extract to the Rats and Measuring Pancreatic Masses}

The treatment group rats were given to extract in each experimental group $(100$ mg/kg, 200 mg/kg, and 400 mg/ $\mathrm{kg}$ extract) at a specified dose of gavage once daily for 28 days. At the end of this period, animals were euthanized, pancreatic masses were obtained and noted.

\section{Statistical Analysis}

Data analysis was performed using the IBM SPSS Statistics 22.0 (IBM Corp., Armonk, New York, USA) statistical software. Regarding descriptive statistics, the number of units (n), percent (\%), mean \pm standard deviation (mean \pm $\mathrm{SD})$, median $\left(25^{\text {th }}-75^{\text {th }}\right.$ percentile) values were reported. The normality distribution of the data with respect to numerical variables was evaluated by Shapiro-Wilk normality test and Q-Q graphs. For normally distributed variables, group comparisons over time were performed using the two-way analysis of variance in repeated measurements, meanwhile, multiple comparisons were performed by use of the Tukey HSD test.

Comparisons of the mean between two groups was done by parametric Student's t-test and comparisons between more than two groups were obtained by the One-Way ANOVA test. The Duncan test was performed to evaluate the significant difference between the groups following obtention of statistically significant ANOVA results. $\mathrm{P}<0.05$ value was considered statistically significant.

\section{RESULT}

Concerning the findings of this study, pancreatic weight was observed to be significantly lower in the diabetic rats $(0.66 \pm 0.20)$ compared to the control rats $(0.88 \pm 0.31)(p<0.05)$. In addition, pancreatic weight increased significantly in every treatment group relative to the control and diabetic groups $(p<0.05)$. The greatest increase was obtained from the extract treated group being $400 \mathrm{mg} / \mathrm{kg}(1.32 \pm 0.16)$ (Figure 1).

\section{DISCUSSION}

Diabetes is a chronic metabolic disease characterized by high blood sugar levels, which, over time, could lead to severe cardiovascular, ocular, renal, and neurological damage. Type II diabetes is most common, and develops especially in adults with insulinoresistance or insulinopenia. Beta cell dysfunction in pancreatic islets is one of the major causes of diabetes (21). Various studies in patients with type II diabetes have revealed a $7 \%-22 \%$ reduction in pancreatic volume using ultrasound, CT, and MRI (22-24). Several

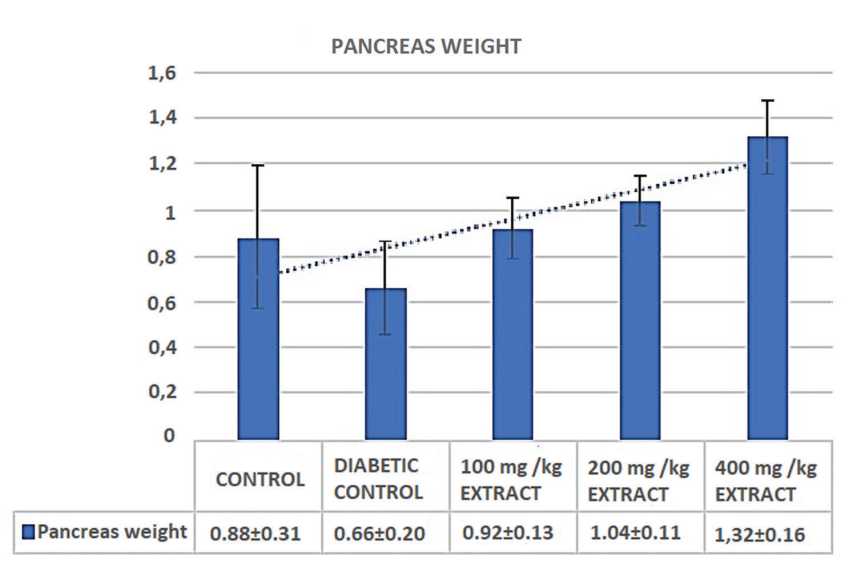

Figure 1. Average pancreatic weight change graphical illustration of experimental rats measured in five groups

studies have been conducted on the recovery of damaged pancreatic $\beta$-cells. In a study involving primates, a slight decrease in pancreatic volume was observed 2-6 months after inhibition of insulin secretion with low dose STZ (25). Against STZ-induced diabetic rats, "G. latifolium" and "O. gratissimum" leaf extracts were found to significantly reduce pancreatic weight (26). In another study, the effect of "M. alba" was investigated on $\beta$-cells in diabetic rats induced by STZ and revealed an increase in $\beta$-cells of groups treated with this plant (27). In addition, another group of researchers examined the effects of STZ-induced diabetes on the body weights of animals and the relative weights of the kidneys, liver, and pancreas. They disclosed that STZ-induced diabetes caused a significant decrease in body weight of diabetic animals, while the relative weights of kidney and liver increased but pancreatic weight was not affected (28). It has been revealed by many studies that a decrease in functional beta cell mass is a distinctive feature of type II diabetes.

It is clearly known in all living beings that cell density can be controlled in a variety of metabolic conditions to maintain a normal blood glucose level. Cells change dynamically in their functions and masses in response to insulin demand (29). Although it has been reported in many studies that both the size and number of islets in the pancreas of patients with type II diabetes have been reported (30-33) in this study, the pancreas of obese rats fed on a high-fat diet was weighed and an increase was observed in diabetic groups compared to control.

It has been reported in some studies that beta cell mass increases due to increased insulin resistance in obesity. Moreover, some studies have revealed that obese mice and rats experience a beta cell mass increase up to four times and a similar situation is observed in obese people, albeit 
less (34-36). Despite the massive increase in obesity-related insulin requirement in obese people, this compensatory increase is thought to occur in the development of diabetes. Inadequate response to this condition is also believedt to be the underlying cause of hyperglycemia and the development of diabetes (37).

In vivo conditions, studies with animal models developed for pancreatic cell regeneration have been effective in setting molecular targets for stimulating cell growth or preventing pancreatic cell death. Loss of functional cells is a very important event in the development of diabetes. In vivo initiation of cell regeneration in the pancreas of diabetic patients seems to be one of the most convenient ways to eliminate the defective cell. For this reason, intensive studies have been performed and still ongoing to identify interactions between the cells in more detail to trigger cell proliferation and/or differentiation in in vivo conditions (38).

\section{CONCLUSION}

In this study, STZ was revealed to cause a decrease in the pancreatic mass of diabetic rats. Moreover, grape seed extract administration resulted in a significant rise in pancreatic mass. Considering other studies supporting this study, it can be concluded that grape seed extract protects pancreatic cells under hyperglycemic conditions and may be effective to correct pancreatic insufficiency in STZinduced diabetic rats.

\section{ACKNOWLEDGMENT}

This study was approved by Selçuk University Scientific Research Projects with the grant number BAP /13201030.

\section{ETHICS}

Ethics Committee Approval: Ethical approval for this study was obtained from the Konya Necmettin Erbakan University Experimental Medical Research Ethics Committee and Application Center for this study (decision no: 2013/005).

Informed Consent: Patient consent was not obtained.

\section{Authorship Contributions}

Surgical and Medical Practices: E.G.M., E.A., H.A., Concept: E.A., H.A., Design: E.A., H.A., Data Collection or Processing: E.G.M., S.V., Analysis or Interpretation: E.G.M., S.V., Literature Search: E.G.M., S.V., Writing: E.G.M., S.V.

Conflict of Interest: No conflict of interest was declared by the authors.

Financial Disclosure: The authors declared that this study received no financial support.

\section{REFERENCES}

1. Tiwari AK, Rao JM. Diabetes mellitus and multiple therapeutic approaches of phyto- chemicals: Present status and future prospects. Curr Sci 2002;83:30-8.

2. Hall JE. Secretory function of the alimentary tract. Guyton \& Hall's textbook of medical physiology 2006;791-807.

3. Abd El-Haleem, Manal Reda; Mohamed, Dalia A. The effects of experimental aflatoxicosis on the pancreas of adult male albino rats and the role of ginger supplementation: a histological and biochemical study. Egyptian Journal of Histology 2011;34:423-35.

4. Burke JP, Williams K, Narayan KM, Leibson C, Haffner SM, Stern MP. A population perspective on diabetes prevention: whom should we target for preventing weight gain? Diabetes Care 2003;26:19992004.

5. Al-Qudah MM, Haddad MA, EL-Qudah JM. The effects of aqueous ginger extract on pancreas histology and on blood glucose in normal and alloxan monohydrate-induced diabetic rats. Biomed Res 2016;27:350-6.

6. Zimmet P, Alberti KG, Magliano DJ, Bennett PH. Diabetes mellitus statistics on prevalence and mortality: facts and fallacies. Nat Rev Endocrinol 2016;12:616-22.

7. Zusman I, Ornoy A, Yaffe P, Shafrir E. Effects of glucose and serum from streptozotocin-diabetic and nondiabetic rats on the in vitro development of preimplantation mouse embryos. Isr J Med Sci 1985;21:359-65.

8. Goud BJ, Dwarakanath V, Chikka B. Streptozotocin-a diabetogenic agent in animal models. Int J Pharm Pharm Res 2015;3:253-69.

9. Vardı N, Uçar M, Iraz M, Öztürk F. Deneysel diyabetin sıçan endokrin pankreasında oluşturduğu morfolojik değişiklikler. Turkiye Klinikleri J Med Sci 2003;23:27-32.

10. İrer SV, Alper G. Deneysel diyabet modelleri. Türk Klinik Biyokimya Derg 2004;2:127-36.

11. West $E$, Simon OR, Morrison EY. Streptozotocin alters pancreatic beta-cell responsiveness to glucose within six hours of injection into rats. West Indian Med J 1996;45:60-2.

12. Özbek H, Özgökçe F, Ceylan E, Taş A, Tunçtürk M. Secale cereale L. (Çavdar) Meyvesi Dekoksiyon Ekstresinin Sağlıklı ve Diyabetli Farelerde Hipoglisemik Etkisinin Araştııılması. Van Tıp Dergisi 2002;9:73-7.

13. Mıcılı SC, Özoğul C. Diyabette kök hücreler. Dokuz Eylül Üniversitesi Tıp Fakültesi Dergisi 2007;21:109-17.

14. Adamson GE, Lazarus SA, Mitchell AE, et al. HPLC method for the quantification of procyanidins in cocoa and chocolate samples and correlation to total antioxidant capacity. J Agric Food Chem 1999;47:4184-8.

15. Gürkan $H$. The importance of the throughout the history of vitis vinifera I. and its use today (Final project). Kayseri: Erciyes University; 2014.

16. Badavi M, Abedi H, Sarkaki A, Dianat M. Exercise Training and Grape Seed Extract Co-administration Improve Endothelial Dysfunction of Mesenteric Vascular Bed in STZ-induced Diabetic Rats. Int J Pharmol 2011;7:813-20.

17. Rostamian V, Shakeri F, Estakhr J. The Effect of Hydro-alcoholic Extract of Grape Seed (Vitis vinifera) on Sugar and Lipids in Serum of Diabetic Rats. Res J Biol Sci 2011;6:547-9.

18. Aşık G. Formaldehit maruziyeti sonucu sıçan testislerinde oluşan morfolojik değişiklikler üzerine üzüm çekirdeği ekstraktının (vitis vinifera) koruyucu etkisi (Yüksek Lisans Tezi). Balıkesir: Balıkesir Üniversitesi; 2016.

19. Downey MO, Mazza M, Krstic MP. Development of a stable extract for anthocyanins and flavonols from grape skin. Am J Enol Vitic 2007;58:358-64. 
20. Srinivasan K, Viswanad B, Asrat L, Kaul CL, Ramarao P. Combination of high-fat diet-fed and low-dose streptozotocin-treated rat: a model for type 2 diabetes and pharmacological screening. Pharmacol Res 2005;52:313-20.

21. Yagihashi S. Advances in pathology of diabetes from pancreatic islets to neuropathy--a tribute to Paul Langerhans. Pathol Int 2015;65:157-69

22. Alzaid A, Aideyan $O$, Nawaz S. The size of the pancreas in diabetes mellitus. Diabet Med 1993;10:759-63.

23. Goda K, Sasaki E, Nagata K, Fukai M, Ohsawa N, Hahafusa T. Pancreatic volume in type 1 and type 2 diabetes mellitus.Acta Diabetol 2001;38:145-49.

24. Burute N, Nisenbaum R, Jenkins DJ, Mirrahimi A, Anthwal S, Colak $E$, et al. Pancreas volume measurement in patients with Type 2 diabetes using magnetic resonance imaging-based planimetry. Pancreatology 2014;14:268-74.

25. Saisho Y, Manesso E, Butler AE, Galasso R, Kavanagh K, Flynn M, et al. Ongoing beta-cell turnover in adult nonhuman primates is not adaptively increased in streptozotocin-induced diabetes. Diabetes 2011;60:848-56.

26. Usoh IF, Akpanyuyng EO. Leaves extracts of Gongronema Latifolium and Ocimum Gratissimum offer synergy on organ weights alleviation and pancreatic resurgence against Streptozotocin diabetic rats. J Innov Pharmaceut Biol Sci 2015;2:522-36.

27. Mohammadi J, Naik PR. The histopathologic effects of Morus alba leaf extract on the pancreas of diabetic rats. Turk J Biol 2012;36:2116.

28. Szkudelski T. The mechanism of alloxan and streptozotocin action in B cells of the rat pancreas. Physiol Res 2001;50:537-46.

29. Yoon KH, Ko SH, Cho JH, Lee JM, Ahn YB, Song KH, et al. Selective beta-cell loss and alpha-cell expansion in patients with type 2 diabetes mellitus in Korea. J Clin Endocrinol Metab 2003;88:23008.

30. Wittingen J, Frey CF. Islet concentration in the head, body, tail and uncinate process of the pancreas. Ann Surg 1974;179:412-4.

31. Orci L, Malaisse-Lagae F, Amherdt M, Ravazzola M, Weisswange A, Dobbs $\mathrm{R}$, et al. Cell contacts in human islets of Langerhans. J Clin Endocrinol Metab 1975;41:841-4.

32. Saito K, Takahashi T, Yaginuma N, Iwama N. Islet morphometry in the diabetic pancreas of man. Tohoku J Exp Med 1978;125:185-97.

33. Baetens D, Malaisse-Lagae F, Perrelet A, Orci L. Endocrine pancreas: three-dimensional reconstruction shows two types of islets of langerhans. Science 1979;206:1323-5.

34. Butler AE, Janson J, Bonner-Weir S, Ritzel R, Rizza RA, Butler PC. Beta-cell deficit and increased beta-cell apoptosis in humans with type 2 diabetes. Diabetes 2003;52:102-10.

35. Bouwens L, Rooman I. Regulation of pancreatic beta-cell mass. Physiol Rev 2005;85:1255-70.

36. Frayling TM. Genome-wide association studies provide new insights into type 2 diabetes aetiology. Nat Rev Genet 2007;8:65762.

37. Mutlu EG. Tip II Diyabetik Ratlarda Vitis Vinifera L. Ekstraktının B-Katenin Geninin Ifadesi Üzerine Etkisi (Doktora Tezi). Konya: Selçuk Üniversitesi; 2016.

38. Figeac F, Uzan B, Faro M, Chelali N, Portha B, Movassat J. Neonatal growth and regeneration of beta-cells are regulated by the Wnt/ beta-catenin signaling in normal and diabetic rats. Am J Physiol Endocrinol Metab 2010;298:E245-56. 